\title{
The diversity in nutritional profile of farmed edible bird's nests from several regions in Indonesia
}

\author{
LINA ELFITA ${ }^{1,2, \vartheta}$, IETJE WIENTARSIH ${ }^{3}$, DONDIN SAJUTHI ${ }^{3}$, INDRA BACHTIAR ${ }^{4}$, \\ HUDA SHALAHUDIN DARUSMAN ${ }^{5}$ \\ ${ }^{1}$ Graduate School, Institut Pertanian Bogor. J1. Raya Dramaga, Bogor 16680, West Java, Indonesia. Tel. +62-812-8696-7548, ^email: \\ lina.elfita@uinjkt.ac.id. \\ ${ }^{2}$ Department of Pharmacy, Faculty of Health Science, Universitas Islam Negeri Syarif Hidayatullah Jakarta. Jl. Ir H. Juanda No. 95, Ciputat, Tangerang \\ Selatan 15412, Banten, Indonesia \\ ${ }^{3}$ Department of Veterinary Clinic Reproduction and Pathology, Faculty of Veterinary Medicine, Institut Pertanian Bogor. Jl. Agatis, Kampus IPB \\ Dramaga, Bogor 16680, West Java, Indonesia \\ ${ }^{4}$ Stem Cell and Cancer Institute, PT Kalbe Farma Tbk. J1. Jend. A. Yani No. 2, Pulomas, Jakarta Timur 13210, Jakarta, Indonesia \\ ${ }^{5}$ Department of Anatomy, Physiology and Pharmacology, Faculty of Veterinary Medicine, Institut Pertanian Bogor. Jl. Agatis, Kampus IPB Dramaga, \\ Bogor 16680, West Java, Indonesia
}

Manuscript received: 29 March 2020. Revision accepted: 5 May 2020

\begin{abstract}
Elfita L, Wientarsih I, Sajuthi D, Bachtiar I, Darusman HS. 2020. The diversity in nutritional profile of farmed edible bird's nests from several regions in Indonesia. Biodiversitas 21: 2362-2368. Edible bird's nest (EBN) is produced by certain swiftlet species mainly Aerodramus fuciphagus. This study aimed to compare the composition of proximate, nitrite, nitrate, amino acid and protein profiles of EBNs collected from different regions in Indonesia (West Sumatra, South Sumatra, West Java, West Kalimantan, Central Sulawesi, and Southeast Sulawesi). The results showed that the order of proximate composition was protein $(53.09-56.25 \%)>$ carbohydrate $(19.57-23.04 \%)>$ moisture $(17.08-21.50 \%)>$ ash $(5.44-6.25 \%)>$ fat $(0.07-0.57 \%)$. Nitrite and nitrate contents were $3.11-$ $18.28 \mathrm{ppm}$ and 650.11-1051.06 ppm, respectively. Amino acid analysis found that EBNs contained 18 amino acids, composed of ten essential amino acids and eight non-essential amino acids. Aspartic acid content of EBNs from West Sumatra and West Kalimantan (4.21 and 3.27\%, respectively) were much higher than the one found in other regions, which was on the range of 0.32-0.37\%. SDSPAGE analysis demonstrated that majority of EBNs possessed seven protein bands with molecular weight range of 19.6 to $82.7 \mathrm{kDa}$. However, EBNs from West Sumatra and West Kalimantan showed abundant of protein with molecular weight of approximately 34.0 $\mathrm{kDa}$. Thus, EBNs collected from different regions in Indonesia showed different nutritional profiles.
\end{abstract}

Keywords: Amino acid, edible bird's nest, Indonesia, nutritional profile, proximate, SDS-PAGE

\section{INTRODUCTION}

Edible bird's nest (EBN) is a nest made of salivary secretions from male swiftlets of genera Aerodramus/ Collocalia, when female swiftlets spawn. EBN is often consumed as healthy and luxury food particularly by Chinese community due to their suggested health benefits. It has also been used for traditional Chinese medicine in China and Southeast Asia, because it is believed that EBN can cure many diseases.

Study of EBN chemical composition is important for understanding its biological activity both as medicine and as functional food. Many studies on chemical composition of EBN, including physicochemical, proximate, amino acid, protein, hormone, sialic acids, and mineral content have been published (Marcone et al. 2005; Huda et al. 2008; Norhayati et al. 2010; Liu et al. 2012; Hamzah et al. 2013; Paydar et al. 2013; Saengkrajang et al. 2013; Helmi et al. 2018; Quek et al. 2018). Those studies found that the composition of EBN consists mainly of protein and carbohydrate, followed by moistures and ash. In addition, EBN also contains fat and trace amount of minerals including sodium, calcium, and magnesium. However, It is well known that the nutrient content of EBN is different, influenced by seasonal variation and breeding sites (Norhayati et al. 2010). This is because different locations have different vegetation and insect population, resulting in variation in macro- and micronutrient composition of EBNs.

Presently, EBN-producing countries are in South-East Asia, with Indonesia, Malaysia, and Thailand producing more than $95 \%$ of the world's supply (swiftletecopark.com.my). As one of mega-biodiversity countries, Indonesia has a diverse avifauna including swiftlets (Collocalia fuciphaga) that in consequent produce a lot of EBNs, and in fact, Indonesia supplies approximately $75 \%$ of the world's EBN market. Nevertheless, studies on the properties and characteristics of EBN from Indonesia are still limited. So far, few studies on nutritional analysis of EBN have been reported, however, the samples were sporadically collected from one or two islands in Indonesia (Huda et al. 2008; Hamzah et al. 2013; Helmi et al. 2018).

The comparison of the nutritional composition of EBN from different regions in Indonesia has important reference value for the EBN commercial development and application. Therefore, the objective of this study was to analyze and compare, in a more systematic manner, the 
chemical composition of EBNs collected from four main islands in Indonesia, which are Sumatra, Java, Kalimantan, and Sulawesi. In addition to the nutritional composition, nitrite, and nitrate contents also become a big concern due to their toxicity. Nitrite has been used as a food preservative and antibotulinal agent in the food processing industry and its level is strictly controlled to prevent food toxicity (DSM 2011). The source of nitrite and nitrate could have been derived from ammonia through anaerobic fermentation by the bacteria in bird soil (Langham 1980). It is also suspected that these variations of nitrite level among EBNs derived from different sources with subjected to different environments, humidity, and climate of the habitat (Jong et al. 2013). Therefore, in this study, we also analyzed nitrite and nitrate composition in EBNs and compared those contents with those in EBNs from surrounding countries.

\section{MATERIALS AND METHODS}

\section{Sample collection and preparation}

EBNs were collected from six EBN farms in four main Islands in Indonesia, which were Sumatra, Java, Kalimantan, and Sulawesi. The location of farms was in Painan in West Sumatra (WS), Sekayu in South Sumatra (SS), Bogor in West Java (WJ), Ketapang in West Kalimantan (WK), Palu in Central Sulawesi (CS) and Bombana in Southeast Sulawesi (SES) (Figure 1). The EBN samples were purchased directly from farmers (20 pieces, approximately $200 \mathrm{~g}$ from each farmer). The EBNs were verified by Research Center for Biology, Indonesian Institute of Sciences (LIPI), and confirmed that all EBNs were from Aerodramus fuciphagus Thunberg, 1812. The EBNs were washed with distilled water, and cleaned to remove dirt and feathers manually by using forceps and scissors. After drying at $60^{\circ} \mathrm{C}$ for 24 hours, the samples were finely ground using a grinder, placed in airtight containers, labeled according to the regions, and kept at room temperature until used for further analysis.

\section{Proximate analysis}

The content of moisture, ash, crude protein, and fat of EBN samples was determined by the official methods of The Association of Official Analytical Chemistry (AOAC). Moisture content was determined by drying $1 \mathrm{~g}$ of EBN samples in an oven at $105^{\circ} \mathrm{C}$ until a constant weight was obtained (AOAC Method 934.01). Ash content was determined by dry ashing $2 \mathrm{~g}$ of EBN samples in a furnace at $550^{\circ} \mathrm{C}$ for 4 hours (AOAC Method 942.05). SemimicroKjeldhal method was used to determine the protein content of EBN by using $1 \mathrm{~g}$ of samples (AOAC Method 2001.11). The Soxtec system was used to determine the fat content. The carbohydrate content was determined by the difference method (subtracting the percent of crude protein, fat, and ash from $100 \%$ of dry EBN samples).

\section{Nitrite and nitrate analysis}

Nitrite and nitrate content were measured by using UVVIS spectrophotometer. $\mathrm{NaNO}_{2}$ and $\mathrm{KNO}_{3}$ and were used as nitrite and nitrate standard, respectively. The nitrite was determined by diazotizing $50 \mathrm{ml}$ water-dissolved EBN samples with $1 \mathrm{~mL}$ of sulfanilamide and coupling with $1 \mathrm{~mL}$ of $N$-(1-naphthyl)-ethylenediamine dihydrochloride to form a highly colored azo dye. The resulting color was measured at a wavelength of $540 \mathrm{~nm}$. The nitrate content was determined by reacting $50 \mathrm{~mL}$ of water-dissolved EBN samples were with $1 \mathrm{~mL}$ of $1 \mathrm{~N} \mathrm{HCl}$. The absorbance and reference were read at $275 \mathrm{~nm}$ and $220 \mathrm{~nm}$, respectively. Concentration of nitrite and nitrate was calculated by using each standard curve.

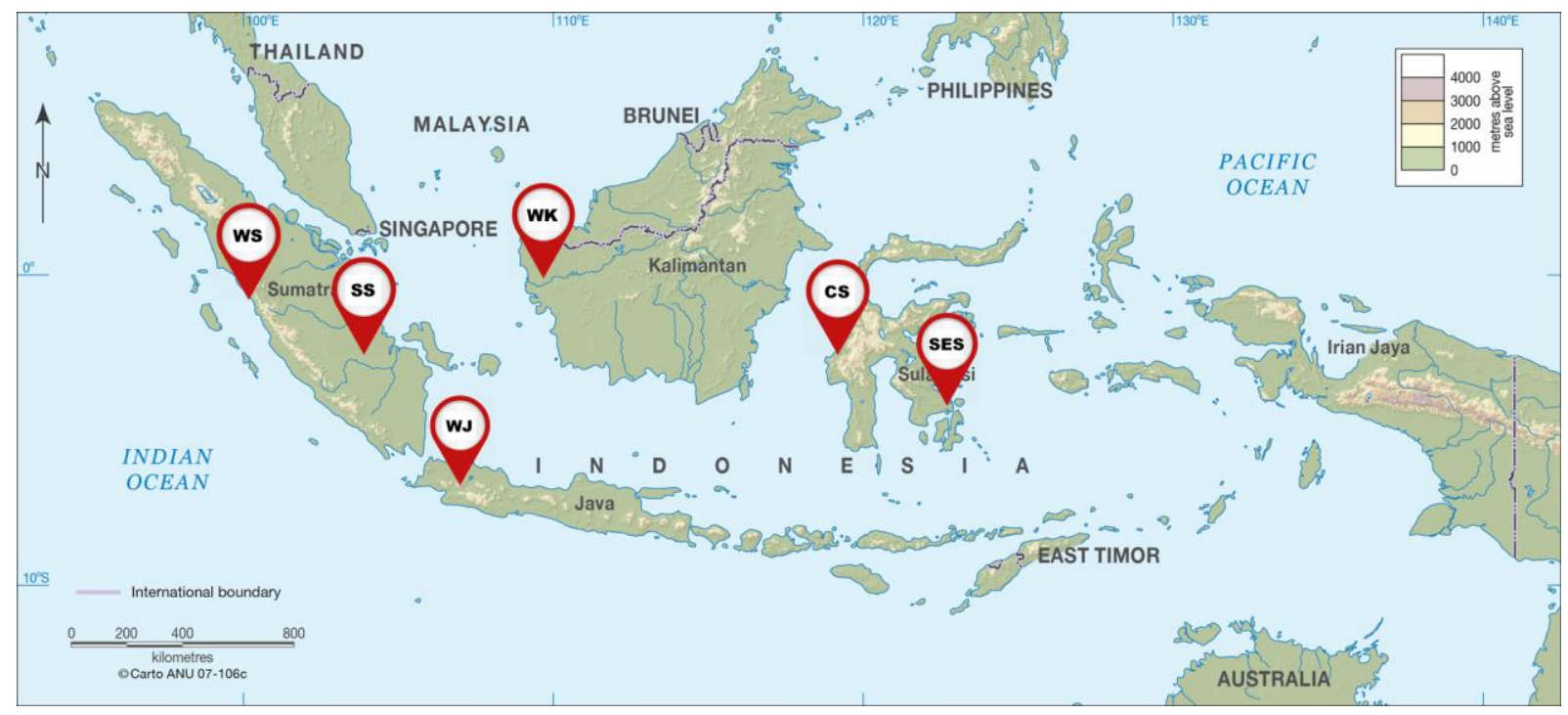

Figure 1. Six locations in where the EBNs were collected (modified from https://asiapacific.anu.edu.au/mapsonline/basemaps/indonesia). WS: West Sumatra; SS: South Sumatra; WJ: West Java; WK: West Kalimantan; CS: Central Sulawesi; SES: Southeast Sulawesi 


\section{Amino acid analysis}

Amino acid analysis was performed by HighPerformance Liquid Chromatography (HPLC) using AccQTag column (3.9 x $150 \mathrm{~mm}$, Waters, USA) with Acetonitrile $60 \%$ as mobile phase and flow rate $1 \mathrm{ml} . \mathrm{min}^{-1}$. Dried EBN samples $(0.1 \mathrm{~g})$ were mixed with $5 \mathrm{~mL}$ of $6 \mathrm{M}$ $\mathrm{HCl}$ at $110^{\circ} \mathrm{C}$ for 22 hours to hydrolyse the protein, diluted into $50 \mathrm{~mL}$ of water and filtered with $0.45 \mu \mathrm{m}$ membrane filter. Hydrolyzed samples $(500 \mu \mathrm{L})$ were mixed with 40 $\mu \mathrm{L}$ of alpha-Aminobutyric acid (AABA) and $460 \mu \mathrm{L}$ water. AccQ-Fluor Borat $(70 \mu \mathrm{L})$ and Fluor A reagent $(20 \mu \mathrm{L})$ were then added into the mixture $(10 \mu \mathrm{L})$, mixed by vortex and kept at $55^{\circ} \mathrm{C}$ for 10 minutes. Five microliters of this sample were loaded into the column. The UV detector was operated at $248 \mathrm{~nm}$ for peak identification, while the excitation and emission wavelengths for fluorescence detector were $250 \mathrm{~nm}$ and $395 \mathrm{~nm}$, respectively, for amino acid quantification. The amount of amino acid was calculated based on the peak area in comparison with standard. Alkaline hydrolysis was done for determination of tryptophan content.

\section{SDS-PAGE}

Ground EBN samples (1.0 g) were dissolved with 30 $\mathrm{mL}$ of $\mathrm{ddH}_{2} \mathrm{O}$ were treated by sonication for 45 minutes, and centrifuged at $10.000 \mathrm{rpm}$ for 30 minutes. The supernatants were dialyzed overnight against $\mathrm{ddH}_{2} \mathrm{O}$ in a dialysis bag with a 3500 cutoff molecular weight. The protein solutions were finally freeze-dried and stored in dark bottles until use. EBN samples were analyzed by $10 \%$ SDS-PAGE, followed by Coomassie brilliant blue R-250 staining. Molecular weight of EBN proteins was calculated from standard curve of relative migrant distance (Rf) versus log of molecular weight of protein markers.

\section{Statistical analysis}

All data were expressed as mean \pm standard deviation. The data were statistically treated by one-way ANOVA, followed by Duncan's test with $\mathrm{p}<0.05$ considered to be statistically significant. The statistical analysis was performed by using SPSS-22 software. Principal Component Analysis (PCA) was carried out for separating EBN samples according to the concentrations of amino acids.

\section{RESULTS AND DISCUSSION}

\section{Proximate analysis}

The proximate composition of EBN collected from various regions in Indonesia is shown in Table 1. The order of the highest to the lowest proximate composition was in the order of protein $(53.09-56.25 \%)>$ carbohydrate $(19.57-23.04 \%)>$ moisture $(17.08-21.50 \%>$ ash (5.44$6.25 \%)>$ fat $(0.07-0.57 \%)$, which was in concordance with previous findings (Marcone 2005; Huda et al. 2008; Saengkrajang et al.2013; Halimi et al. 2014).

Protein, the largest constituent, was found to be in the range of 53.09-56.25\% (average 54.58\%), with the highest and the lowest protein content was found in EBNs from WS (56.25\%) and SS (53.09\%), respectively. The protein content of EBN from WS differed significantly from protein value of EBNs from other regions $(P<0.05)$. These findings, as expected, indicated that geographical location affects the protein content of EBN. The protein content in this study, however, was little bit lower than those of EBNs collected from Thailand, which was 60.9-66.9\% (Saengkrajang et al. 2013), EBNs from Malaysia (Perlis and Langkawi) and Indonesia (Java, Kalimantan and Balikpapan), which was 59.8-65.8\% (Hamzah et al. 2013), but similar to those of EBNs from Malaysia (Pahang and Terengganu), which was $55.48-58.55 \%$ (Halimi et al. 2014), and higher than those EBNs from Malaysia (Penang), which was 24.36-49.30\% (Huda et al. 2008). Protein value is closely related to availability of good feeding environment and abundance of feed in the area (Huda et al. 2008). Protein is a major component in EBN accounting for 50-65\% of dried weight EBN and it plays a key role in nutritious and pharmacological effects, and it also may have important biological functions (Ma and Liu 2012). It has been reported that protein in EBN, lactoferrin, and ovotransferrin attenuated $\mathrm{H}_{2} \mathrm{O}_{2}$-induced cytotoxicity, and decreased radical oxygen species in human SH-SY5Y cells through increased scavenging activity (Hou et al. 2015). Although the protein content of EBNs from WS was significantly different from protein contents from other regions, the protein contents in this study were still in the range of protein content of EBNs from surrounding countries. A slight difference in the content may be due to the difference in the environment, but not due to the difference in climate or seasons.

Table 1. Proximate composition of EBNs from several regions in Indonesia

\begin{tabular}{|c|c|c|c|c|c|c|}
\hline \multirow{2}{*}{$\begin{array}{l}\text { Proximate } \\
\text { composition }(\%)\end{array}$} & \multicolumn{6}{|c|}{ EBN samples* } \\
\hline & WS & SS & WJ & WK & CS & SES \\
\hline Protein & $56.25 \pm 0.06^{\mathrm{a}}$ & $55.66 \pm 0.11^{b}$ & $53.38 \pm 0.04^{\mathrm{c}}$ & $53.45 \pm 0.04^{\mathrm{c}}$ & $55.67 \pm 0.04^{b}$ & $53.09 \pm 0.07^{d}$ \\
\hline Carbohydrate & $20.29 \pm 0.08^{\mathrm{d}}$ & $19.84 \pm 0.06^{\mathrm{e}}$ & $20.70 \pm 0.11^{\mathrm{c}}$ & $23.04 \pm 0.10^{\mathrm{b}}$ & $20.80 \pm 0.06^{\mathrm{c}}$ & $19.57 \pm 0.03^{f}$ \\
\hline Moisture & $17.08 \pm 0.04^{\mathrm{e}}$ & $18.33 \pm 0.06^{\mathrm{c}}$ & $19.55 \pm 0.01^{\mathrm{b}}$ & $17.65 \pm 0.06^{\mathrm{d}}$ & $17.74 \pm 0.04^{\mathrm{d}}$ & $21.50 \pm 0.11^{\mathrm{a}}$ \\
\hline Ash & $6.25 \pm 0.06^{\mathrm{a}}$ & $5.79 \pm 0.08^{b}$ & $5.80 \pm 0.01^{\mathrm{b}}$ & $5.46 \pm 0.06^{\mathrm{cd}}$ & $5.73 \pm 0.01^{\mathrm{b}}$ & $5.44 \pm 0.00^{\mathrm{d}}$ \\
\hline Fat & $0.14 \pm 0.00^{\mathrm{d}}$ & $0.39 \pm 0.02^{\mathrm{c}}$ & $0.57 \pm 0.07^{\mathrm{b}}$ & $0.41 \pm 0.02^{\mathrm{c}}$ & $0.07 \pm 0.01^{\mathrm{d}}$ & $0.41 \pm 0.01^{\mathrm{c}}$ \\
\hline
\end{tabular}

Note: *WS: West Sumatra; SS: South Sumatra; WJ: West Java; WK: West Kalimantan; CS: Central Sulawesi; SES: Southeast Sulawesi. a-f: same letter in each category raw are not significantly different $(P \geq 0.05)$ 
Carbohydrate contents of EBNs examined in this study were between $19.57-23.04 \%$ with an average value of $20.71 \%$. The highest carbohydrate content was found in EBN from WK $(23.04 \%)$, while the lowest carbohydrate content was found in EBN from SES (19.57\%). The carbohydrate values of EBNs from WK differed significantly from carbohydrate values of EBNs from other regions $(P<0.05)$. These carbohydrate contents were lower than those of EBNs from Malaysia (Penang), which were 27.57-58.21\% (average 35.44\%) (Huda et al. 2008), from Thailand, which was 25.4-31.4\% (average 29.66\%) (Saengkrajang et al. 2013), but similar to those of EBNs from Malaysia (Pahang and Terengganu), which were 22.28-25.79\% (average 24.04\%) (Halimi et al. 2014). These carbohydrate values, however, were higher than those of EBNs from Malaysia (Perlis and Langkawi) and previous reports from Indonesia (Java, Kalimantan, and Balikpapan), which were 8.5-16.4\% (Hamzah et al. 2013). Carbohydrates in the EBNs were shown to be composed of 9\% sialic acid, $7.2 \%$ galactosamine, $5.3 \%$ glucosamine, $16.9 \%$ galactose, and $0.7 \%$ fucose (Ma and Liu 2012). Similar to the protein content, the carbohydrate content of EBNs from WK was significantly different from that of other regions, however overall carbohydrate composition in this study was also in the range of carbohydrate content of EBNs from surrounding countries, perhaps due to similar climate and environment.

Moisture content was in the range of $17.08-21.50 \%$ (average 18.64\%), with the lowest and highest content was in EBN sample from WK and SES, respectively. Moisture content was found to be significantly different among EBNs $(P<0.05)$. The content of moisture was much higher than those of EBNs from Malaysia (Perlis and Langkawi) and Indonesia (Java, Kalimantan, and Balikpapan), which was $10.87-13.88 \%$ (average 12.94\%) (Hamzah et al. 2013) and EBNs from Malaysia (Pahang and Terengganu), which was $15.87-15.90 \%$ (average 15.89\%) (Halimi et al. 2014), slightly higher than those of EBNs from Malaysia (Penang), which was 13.77-20.20\% (average 16.15\%) (Huda et al. 2008), but slightly lower than to those of EBNs collected from Thailand, which was $17.8-24.3 \%$ (average $19.82 \%$ ) (Saengkrajang et al. 2013). The moisture content is frequently used as an index of stability and quality of edible bird's nest (Hamzah et al. 2013). Interestingly, moisture content was significantly different among almost all EBNs used in this study. It is suggested that moisture is sensitive parameter that might be influenced by the environment of the farm, however, further investigation is needed.

The content of ash was in the range of 5.44-6.25\% (average $5.75 \%$ ). Statistical analysis showed that only ash content of EBN from WS was significantly different with ash content of EBNs from other regions, The ash content in this study was lower than to those of EBNs collected from Thailand, which was 5.9-7.4\% (average 6.72\%) (Saengkrajang et al. 2013), but much higher than those of EBNs Malaysia (Pahang and Terengganu), which was 2.57-2.60\% (average 2.59\%) (Halimi et al. 2014). It is similar to those of EBNs from Malaysia (Penang), which was in average of $5.35 \%$, although EBNs from Penang contains wide range of ash content (2.75-7.53\%) (Huda et al. 2008). In opposite to moisture content, the ash content was almost the same within all EBNs used in this study, different from the ash content in EBNs from Malaysia which had quite wide range.

Fat, the smallest constituent, was found to be significantly different among the EBNs from different locations. The fat content was in between $0.07-0.57 \%$ (average $0.33 \%$ ), with the highest and the lowest contents were in EBNs from West Java and Central Sulawesi, respectively. Statistical analysis categorized fat content in this study into 3 groups, i.e. group 1 which was $\mathrm{WJ}$, group 2 which were SS, WK and SES, and group 3 which included WS and CS. This percentage of fat content in this study was similar to those of EBNs Malaysia (Pahang and Terengganu), which was $0.29-0.67 \%$ (average $0.48 \%$ ) (Halimi et al. 2014), but much lower than to those of EBNs collected from Thailand, which was $0.4-1.3 \%$ (average $0.96 \%$ ) (Saengkrajang et al. 2013) and EBNs from Malaysia (Penang), which was $0.47-2.00 \%$ (average $0.80 \%$ ) (Huda et al. 2008). However, all those reports have shown much high fat content compared to those which reported by Hamzah et al (2013), where the fat content was extremely low (0.04-0.07\% for unclean EBNs and 0.01$0.05 \%$ for clean EBNs). Fat content is one concern of customers when they choose EBNs to consume and low-fat content is preferable.

\section{Nitrite and nitrate concentration}

Nitrite and nitrate contents of EBNs used in this study were shown in Table 2. Nitrite contents were found to be in the range of 3.11-18.28 ppm (average $8.40 \mathrm{ppm}$ ), with the highest and lowest nitrite content in EBNs from CS and WJ, respectively. On the other hand, the content of nitrate was in between 650.11-1,051.06 ppm (average 881.52 ppm), with the highest and lowest nitrate content in EBNs from WK and SES, respectively. The results showed that in average nitrate content was 105 -fold higher than nitrite content. This is likely because nitrate is a more stable ion and can be generated from nitrite oxidation. According to Malaysian Food Regulation 1985 and Malaysia Standard MS2334:2011, raw EBNs which have undergone a cleaning process should contain no more than $30 \mathrm{ppm}$ of nitrite contents. All EBNs collected in this study have satisfied the requirement.

In previous study, Hamzah et al. (2013) reported that clean EBNs collected from Kalimantan and Perlis were devoid of nitrite and nitrate. Although they found nitrite in clean EBNs from Java, Balikpapan, and Langkawi, the concentration was extremely low $(\leq 0.5 \mathrm{ppm})$. In addition, Paydar et al. (2013) reported that the nitrite and nitrate concentration of house EBNs from Malaysia was in the range of 7.9-22.0 ppm (average $14.3 \mathrm{ppm}$ ) and 20.4-87.4 ppm (average $43.9 \mathrm{ppm}$ ), respectively. Thus, the nitrite and nitrate concentration of EBNs used in this study were much higher compared to that of Malaysia. Since the variation of nitrite and nitrate level of EBNs from different sources is associated with the difference in environment, humidity, and climate of the habitat (Jong et al. 2013), it is suggested that this difference was due to difference in environment of 
the EBN farms, however, more research is required in order to elucidate the reasons of high content of nitrite and nitrate of EBNs used in this study.

\section{Amino acid composition}

Amino acid analysis showed that EBNs collected from different locations in Indonesia contained 18 amino acids, including ten essential amino acids and eight nonessential amino acids (Table 3). The highest and lowest total amino acid content were found in EBNs from WS and WK, respectively. This is in line with the protein content where EBN from WS showed the highest content (Table 1). The content of essential amino acids ranged between 16.15 and $20.88 \%$. EBN collected from WK contained the lowest essential amino acids (16.15\%) compared to those from other locations. On the other hand, EBN from WS showed the highest amount of essential amino acid (20.54\%). Saengkrajang et al. (2013) reported that methionine (an essential amino acid) and cysteine (a nonessential amino acid) were the major amino acids in EBNs from Thailand, however, in this study we found that those amino acids were among the lowest percentage in EBNs. Study from Malaysia also reported that methionine was the minor amino acids in house bird's nest from Selangor and Borneo (Ismail et al. 2013). From EBNs examined our this study, it was found that leucine, phenylalanine, threonine, and valine were major essential amino acids, similar to another report from Malaysia, in which valine, lysine, and leucine were the major essential amino acid in EBNs collected from Pahang and Terengganu (Halimi et al. 2014).

On the other hand, nonessential amino acid content was higher than essential amino acids, ranged between 21.28 and $27.84 \%$. EBN collected from WK also contained a smaller amount of nonessential amino acid compared to those from other locations. Similar to essential amino acids, EBN from WS showed the highest amount of nonessential amino acid (27.84\%). The highest content of nonessential amino acid found in EBNs examined was serine, however arginine, glutamic acid, proline, and tyrosine were also high. These results are different from EBNs of Thailand, in which glutamine was most abundant (Saengkrajang et al. 2013) and EBNs from Malaysia, in which glutamic acid and aspartic acid were most abundant (Halimi et al. 2014). In our study, aspartic acid was found extremely high in EBNs from WS (4.21\%) and WK (3.27\%), while in EBNs from other locations was very low $(0.32-0.37 \%)$.
All EBNs examined showed various concentrations of amino acids. Serine (4.57\%) demonstrated the highest concentration and methionine $(0.12 \%)$ demonstrated the lowest contents. EBN from WS showed the highest content of amino acid content (48.38\%). In addition, it was also demonstrated a unique characteristic in terms of content of several amino acids, such as serine $(5.02 \%)$, aspartic acid $(4.21 \%)$ and histidine $(2.13 \%)$, with higher concentration than that EBNs from other locations (Table 3).

Furthermore, principal component analysis (PCA) was able to separate EBN samples from each location (Figure 2). The two first principal components explained $94.84 \%$ of the total variance in the dataset: F1 accounted for $77.71 \%$ and $\mathrm{F} 2$ for $17.13 \%$. PCA revealed SS, CS, and WJ have similar amino acid composition compared to other EBNs and were characterized by high isoleucine and methionine. EBN from WK was characterized by low concentration of leucine, valine, and lysine compared to EBNs from other locations. EBN from WS was characterized by high histidine content, however, EBN from SES has very low histidine content.

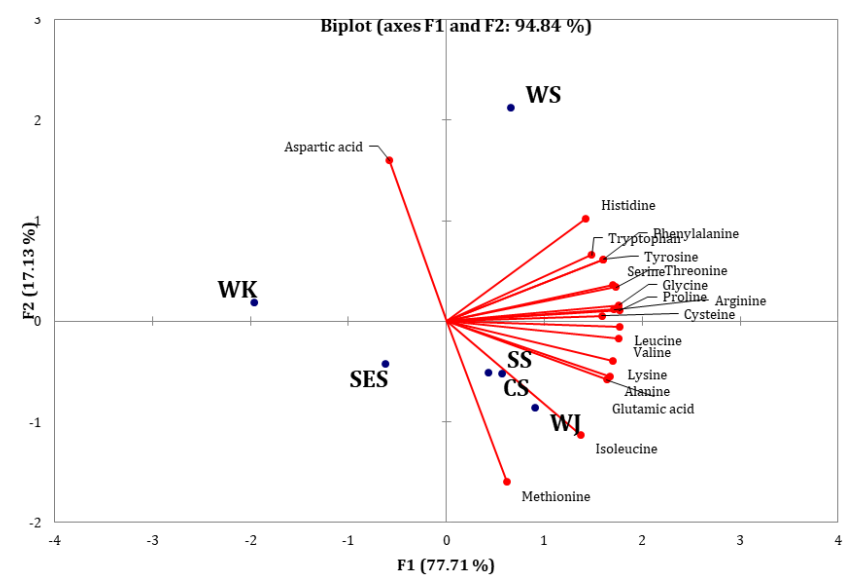

Figure 2. Principal component analysis (PCA) of amino acid data from Table 3. The biplot shows amino acid data and location as vectors. Vectors that are close together are correlated in terms of amino acid composition for each location. *Note: WS: West Sumatra, SS: South Sumatra, WJ: West Java, WK: West Kalimantan, CS: Central Sulawesi, SES: Southeast Sulawesi.

Table 2. Composition of nitrite and nitrate of EBNs from several regions in Indonesia

\begin{tabular}{lcccccc}
\hline $\begin{array}{l}\text { Proximate } \\
\text { composition } \\
(\%)\end{array}$ & WS & SS & WJ & WK & CS & SES \\
\cline { 2 - 7 } & \multicolumn{1}{c}{ WS samples* } & \\
\hline Nitrite & $13.58 \pm 4.83^{\mathrm{b}}$ & $3.98 \pm 0.89^{\mathrm{e}}$ & $3.11 \pm 0.83^{\mathrm{e}}$ & $6.31 \pm 1.87^{\mathrm{c}}$ & $18.28 \pm 1.07^{\mathrm{a}}$ & $5.13 \pm 4.74^{\mathrm{d}}$ \\
Nitrate & $1,049.32 \pm 1.52^{\mathrm{a}}$ & $713.22 \pm 2.64^{\mathrm{c}}$ & $797.99 \pm 2.80^{\mathrm{b}}$ & $1,051.06 \pm 2.60^{\mathrm{a}}$ & $1,027.39 \pm 1.23^{\mathrm{a}}$ & $650.11 \pm 2.83^{\mathrm{d}}$ \\
\hline
\end{tabular}

Note: *WS: West Sumatra, SS: South Sumatra, WJ: West Java, WK: West Kalimantan, CS: Central Sulawesi, SES: Southeast Sulawesi. a-f: same letter in each category column are not significantly different $(P \geq 0.05)$ 
Table 3. Amino acid composition of EBNs from several regions in Indonesia

\begin{tabular}{|c|c|c|c|c|c|c|c|}
\hline \multirow{2}{*}{ Group } & \multirow{2}{*}{ Amino acid } & \multicolumn{6}{|c|}{ AA composition (\%) of EBN samples } \\
\hline & & WS* & $\mathbf{S S}^{*}$ & WJ* & WK* & $\mathrm{CS}^{*}$ & SES* \\
\hline \multirow{10}{*}{ Essential } & Histidine & 2.13 & 1.85 & 1.86 & 1.56 & 1.83 & 1.61 \\
\hline & Isoleucine & 1.44 & 1.60 & 1.68 & 1.36 & 1.61 & 1.50 \\
\hline & Leucine & 3.63 & 3.59 & 3.77 & 2.80 & 3.58 & 3.21 \\
\hline & Lysine & 2.14 & 2.29 & 2.34 & 1.70 & 2.28 & 1.91 \\
\hline & Methionine & 0.06 & 0.15 & 0.16 & 0.10 & 0.13 & 0.10 \\
\hline & Phenylalanine & 3.52 & 3.24 & 3.36 & 2.78 & 3.20 & 3.16 \\
\hline & Threonine & 3.62 & 3.37 & 3.54 & 2.73 & 3.42 & 3.14 \\
\hline & Tryptophan & 0.55 & 0.54 & 0.53 & 0.51 & 0.54 & 0.52 \\
\hline & Valine & 3.45 & 3.46 & 3.64 & 2.61 & 3.44 & 3.14 \\
\hline & Subtotal & 20.54 & 20.09 & 20.88 & 16.15 & 20.03 & 18.29 \\
\hline \multirow[t]{10}{*}{ Non-essential } & Alanine & 1.32 & 1.43 & 1.53 & 0.96 & 1.40 & 1.29 \\
\hline & Arginine & 3.42 & 3.39 & 3.45 & 2.62 & 3.16 & 3.11 \\
\hline & Aspartic acid & 4.21 & 0.37 & 0.32 & 3.27 & 0.37 & 0.34 \\
\hline & Cysteine & 0.65 & 0.69 & 0.64 & 0.50 & 0.60 & 0.57 \\
\hline & Glutamic acid & 3.51 & 3.68 & 4.15 & 2.72 & 3.90 & 3.31 \\
\hline & Glycine & 2.06 & 2.01 & 2.03 & 1.54 & 2.01 & 1.77 \\
\hline & Proline & 3.90 & 3.77 & 3.94 & 2.94 & 3.79 & 3.36 \\
\hline & Serine & 5.02 & 4.64 & 4.89 & 3.83 & 4.85 & 4.19 \\
\hline & Tyrosine & 3.75 & 3.53 & 3.56 & 2.96 & 3.36 & 3.34 \\
\hline & Subtotal & 27.84 & 23.51 & 24.51 & 21.34 & 23.44 & 21.28 \\
\hline Total & & 48.38 & 43.60 & 45.39 & 37.49 & 43.47 & 39.57 \\
\hline Essential/total & & 0.42 & 0.46 & 0.46 & 0.43 & 0.46 & 0.46 \\
\hline
\end{tabular}

Note: *WS: West Sumatra, SS: South Sumatra, WJ: West Java, WK: West Kalimantan, CS: Central Sulawesi, SES: Southeast Sulawesi

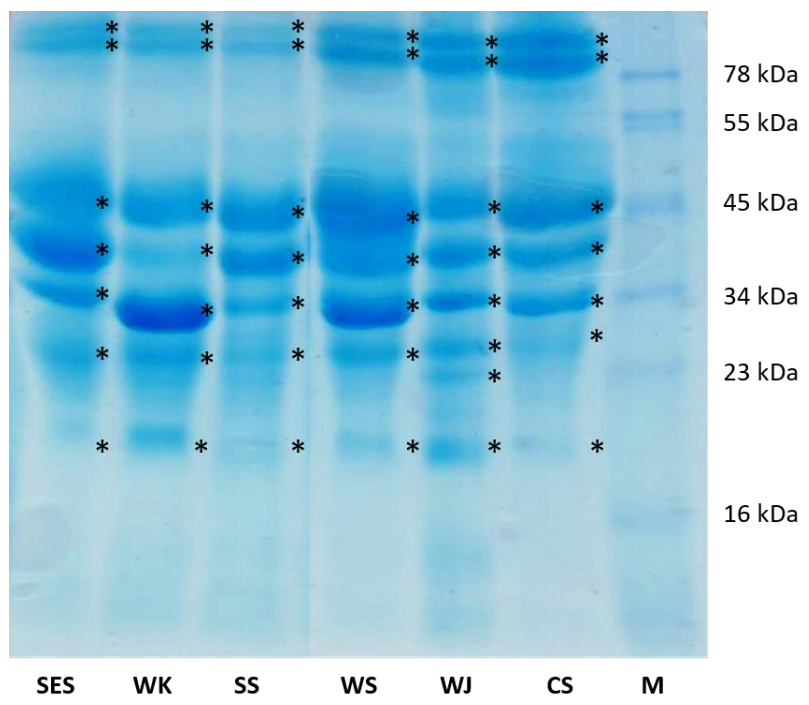

Figure 3. Protein profile of six EBNs collected from different regions in Indonesia. WS: West Sumatra, SS: South Sumatra,WJ: West Java, WK: West Kalimantan, CS: Central Sulawesi, SES: Southeast Sulawesi

\section{SDS-PAGE analysis}

SDS-PAGE analysis showed that in general, all EBNs had similar protein profiles (Figure 3). Most EBNs consisted of seven proteins with molecular weight of approximately $19.6 \mathrm{kDa}, 26.8 \mathrm{kDa}, 34.0 \mathrm{kDa}, 37.5 \mathrm{kDa}$, $45.0 \mathrm{kDa}, 76.9 \mathrm{kDa}$, and $82.7 \mathrm{kDa}$, respectively. However, EBN from WS showed extremely high intensity of protein band with molecular weight of approximately $34.0 \mathrm{kDa}$. EBN from WK also possessed higher amounts of $34.0 \mathrm{kDa}$ protein, instead, it had smaller amounts of $37.5 \mathrm{kDa}$ protein. EBN from SS, on the other hand, has shown less $31.7 \mathrm{kDa}$ protein. Furthermore, EBN from WJ showed a slightly different pattern; it possessed an extra abundant protein with molecular weight of approximately $23.0 \mathrm{kDa}$ in addition to seven protein bands shown by majority of EBNs. Based on the intensity of the total protein bands it seems that EBN from WS and WK showed the strongest and the weakest intensity, respectively, suggesting that the SDS-PAGE results were in line with amino acid results (Table 3). Although EBN from WK showed strong intensity in protein with molecular weight of $34.0 \mathrm{kDa}$, the intensity of proteins with other molecular weight is very weak. The result of SDS-PAGE analysis of EBNs used in this study is different with previous study, in which wider ranges of molecular weight of proteins (18-552 $\mathrm{kDa}$ ) were detected in EBNs from Kalimantan and Java (Helmi et al. 2018). These results imply that EBNs from different locations have different protein profiles.

In conclusion, all EBNs collected from WS, SS, WJ, WK, CS, and SES showed different nutritional profiles. Furthermore, their nutritional profiles were also different from that of EBNs of Malaysia and Thailand. Based on our knowledge, this study was the first comprehensive investigation on nutritional profile of EBNs collected from several regions in Indonesia. So far, only proximate analysis and protein profile of EBNs from Kalimantan and Java have been reported in separate investigations. Furthermore, no report on amino acid composition of 
EBNs from Indonesia has been published. Thus, we believe that this comprehensive analysis will be an important reference and will be beneficial for the commercial development and application of EBN in Indonesia. However, since this study only investigated nutritional profile of EBNs collected from few farms in each Island, more extensive study on nutritional profile of EBNs from other locations in Indonesia is needed in order to obtain a complete picture of EBNs character in Indonesia.

\section{ACKNOWLEDGEMENTS}

The authors thank Patrick T. Reilly, Ph.D. (Institut Clinique de la Souris, France) for critical reading of the manuscript.

\section{REFERENCES}

AOAC. 2005. AOAC official methods of analysis. 17th ed. Association of Official Analytical Chemistry. Washington, DC.

Department Standard Malaysia (DSM). 2011. Edible-birdnest (EBN)Specification. MS 2334:2011.

Halimi NM, Kasim ZM, Babji AS. 2014. Nutritional composition and solubility of edible bird nest (Aerodramus fuchiphagus). AIP Conf Proc 1614: 476-481. DOI: 10.1063/1.4895243

Hamzah Z, Ibrahim NH, Sarojini J, Hussin K, Hashim O, Lee BB. 2013. Nutritional properties of edible bird nest. J Asian Sci Res 3: 600-607.

Helmi Z, Subekti DT, Mranata B, Sudarnika E, Lukman DW, Wibawan IWT. 2018. Protein profile of edible bird's nest origin Kalimantan and Java islands Indonesia. IOSR-JAVS 11: 69-73. DOI: 10.9790/2380 1105026973

Hou Z, Imam MU, Ismail M, Azmi NH, Ismail N, Ideris A, Mahmud R. 2015. Lactoferrin and ovotransferrin contribute toward antioxidative effects of Edible Bird's Nest against hydrogen peroxide-induced oxidative stress in human SH-SY5Y cells. Biosci Biotechnol Biochem 79: 1570-1578. DOI: 10.1080/09168451.2015.1050989

Huda MZN, Zuki ABZ, Azhar K, Goh YM, Suhaimi H, Hazmi AJA, Zairi MS. 2008. Proximate, elemental and fatty acid analysis of preprocessed edible birds' nest (Aerodramus fuciphagus): a comparison between regions and type of nest. J Food Technol 6: 39-44.

Ismail A, Amin MA, Hashim DM, Ismail A. 2013. Using amino acids composition combined with principal component analysis to differentiate house and cave bird's nests. Curr Trends Tech Sci 2: 363-366.

Jong CH, Tay KM, Lim CP. 2013. Application of the fuzzy Failure Mode and Effect Analysis methodology to edible bird nest processing. Comput Electr Agric 96: 90-108. DOI: 10.1016/j.compag.2013.04.015

Langham N. 1980. Breeding biology of the edible-nest Swiftlet Aerodramus fuciphagus. IBIS 122: 447-461). DOI: 10.1111/j.1474919X.1980.tb00900.x Liu X, Lai X, Zhang S, Huang X, Lan Q, Li Y, Li B, Chen W, Zhang Q, Hong D, Yang G. 2012. Proteomic profile of edible bird's nest proteins. J Agric Food Chem 60: 12477-12481. DOI: $10.1021 /$ jf303533p

Ma F, Liu D. 2012. Sketch of the edible bird's nest and its important bioactivities. Food Res Int 48: 559-567. DOI: 10.1016/j.foodres.2012.06.001

Marcone MF. 2005. Characterization of the edible bird's the "Caviar of the East". Food Res Intl 38: 1125-1134. DOI: 10.1016/j.foodres.2005.02.008

Norhayati MK, Azman O, Nazaimoon WMW. 2010. Preliminary study of the nutritional content of Malaysian edible bird's nest. Malays J Nutr 16 (3): 389-96.

Paydar M, Wong YL, Wong WF, Hamdi OA, Kadir NA, Looi CY. 2013. Prevalence of nitrite and nitrate contents and its effect on edible bird nest's color. J Food Sci 78: T1940-T1947. DOI: 10.1111/1750-3841.12313

Quek MC, Chin NL, Yusof YA, Law CL, Tan SW. 2018. Characterization of edible bird's nest of different production, species and geographical origins using nutritional composition, physicochemical properties and antioxidant activities. Food Res Intl 109: 35-43. DOI: 10.1016/j.foodres.2018.03.078

Saengkrajang W, Matan N, Matan N. 2013. Nutritional composition of the farmed edible bird's nest (Collocalia fuciphaga) in Thailand. J Food Compos Anal 31: 41-45. DOI: 10.1016/j.jfca.2013.05.001 